\title{
Leadership Style and Principal Supervision in Improving Teacher Performance at State High Schools in Kutai Kartanegara Regency, East Kalimantan Province, Indonesia
}

\author{
Warman $^{\mathrm{a}^{*}}$, Soerjo Adi Poernomo ${ }^{\mathrm{b}}$, Syafrudin Januar ${ }^{\mathrm{b}}, \&$ Lorensius Amon ${ }^{\mathrm{c}}$ \\ ${ }^{a}$ Mulawarman University, Samarinda, Indonesia \\ ${ }^{b}$ Country Education Quality Assurance Institute for East Kalimantan Province, Indonesia \\ ${ }^{c}$ STKPK Bina Insan the Archdiocese of Samarinda, Indonesia
}

\begin{abstract}
This study examines the leadership style and supervision of principals in improving teacher performance in several public high schools in Kutai Kartanegara Regency, East Kalimantan Province. This study uses a qualitative approach with a cross-sectional descriptive method. Observation and interview techniques were used to obtain data. The collected data were analyzed in the form of data reduction, data presentation, and conclusion drawing, as well as checking the validity of the data using observation and triangulation. The results of this study indicate that the principals' leadership style in improving teacher performance is a leadership style democratic and authoritarian. Authoritarian style is done through observation timeliness of attendance of teachers in schools and teaching time in the classroom. The democratic style is carried out by providing opportunities for teachers to attend training according to the needs of the school and the needs of teachers. The Teaching supervision program principal's oriented towards the guidance of teachers' tasks, such as preparing teaching programs and preparing learning tools. Obstacles in the supervision of principals are the low competence of most supervisors, activities outside the supervision schedule, and difficulty changing old habits.
\end{abstract}

Keywords: Leadership style; Supervision; High school; East Kalimantan

\section{Introduction}

School leaders play an important role in developing schools. The process of change depends on the capacity of school leaders to lead the collective learning process in schools through collaborative and informed reflection activities relevant to the needs of the school (Kovačević \& Hallinger, 2019). The role of the principal has undergone major changes, has become more complex, and shifted from the role of building manager to that of a visionary instructional leader (Dagnew Kelkay, 2020). The leadership literature talks a lot about models and instruments, describing different leadership styles that are considered important, for example the paradigm of leadership and service leadership (Lorensius, Warman, et al., 2021). In terms of supervision, the principal has a supervising role by adjusting communication and interaction styles with the aim of improving teacher performance as well as enacting discourse and principal policy steps towards increasing principal autonomy (Drummer et al., 2018; Warman, Lorensius, et al., 2021). Historically, the principal role of principals, especially in Asian countries, has been managerial and political (Hallinger, 2004; Walker et al., 2012). In Indonesia, principals are formally placed in schools as government "officers". However, the limitations of their configuration of roles in achieving education reform are gradually becoming apparent to policy makers. Perspectives and activities associated with a strong managerial and political focus in leadership are usually aimed at maintaining stability (Hallinger, 2004; Warman, 2021).

In Indonesia, leadership is needed to manage school development work and sustain change to improve student learning (Aas \& Paulsen, 2019). Leadership is an important factor in supporting the achievement of school

\footnotetext{
* Corresponding author.

E-mail address: warman@fkip.unmul.ac.id (Warman)
} 
organizational goals. The success of the principal in school management, managing school infrastructure, fostering teachers, or managing other school activities is largely determined by the principal's leadership (Manora, 2019). Principals are required to be able to lead as well as supervise and manage learning activities held at the schools they lead, so that they aim to improve the quality of education (Anggal et al., 2019). As leaders and supervisors, principals must be able to give attention, encourage and motivate teachers so that they are enthusiastic in working so as to produce better performance (Mustaghfiroh et al., 2020). The fact shows that the principal as a supervisor has not fully implemented supervision, it can be seen that supervision is carried out only once in a semester (Rohaenah et al., 2020). The results of supervision carried out as a condition for filing for disbursement of funds for teachers to obtain professional allowances. The principal as a direct leader is a real example in activities as well as being the highest leader of an educational unit that oversees staff consisting of educators and education staff (Lie et al., 2014; Donkoh \& Baffoe, 2018).

In simple terms, the principal can be defined as a functional teacher who is given additional duties to lead an institution or school where the teaching and learning process is held, or a place where there is interaction between teachers who give lessons and students who receive lessons (Rizkita \& Supriyanto, 2020). Given the strategic position of a school principal, the appointment of a principal must go through a process and procedure based on applicable regulations. Appointment procedures provide clues about educational resources and background, experience, age, rank and integrity (Rowland, 2017). Meanwhile, the Minister of Education and Culture Regulation Number 6 of 2018 concerning the assignment of teachers as principals emphasizes the requirements or criteria that prospective school principals need to meet. Competence as the ability to carry out tasks is obtained through education and training according to certain standards and qualities with the tasks to be carried out. Performance is the ability to do something or perform (Andriani et al., 2018). Performance or performance is the result of work from a process which means the work achieved by an employee in carrying out the tasks assigned to him. Teacher performance indicators consist of professional performance, appearance and skills (Sodik et al., 2019). With regard to the importance of assessing teacher performance, it is very necessary for school principals to carry out continuous supervision activities as supervisors by improving their approach to curriculum supervision through the application of the supervisory process (organizing, planning, dealing with change, implementing, solving problems, and evaluating) to the six levels of the curriculum. (written, taught, resourced, experienced, tested, and ideal) and uses three supervisory roles, namely as monitor, standard bearer, and first teacher (Yulieana, 2020; Thessin, 2019).

Supervision is carried out to improve and enhance the learning process to improve the performance of a teacher, because supervision is an attempt to improve the learning process, namely by helping teachers improve the quality of teaching to help students learn better (Kaso et al., 2021). This supervision can be carried out by the principal and the supervisor or appointed senior teacher. The main mission of educational supervision is to provide teacher assistance to improve the learning process, facilitate and motivate teachers to teach efficiently, so that the quality of education increases (Irmayani et al., 2018). Teaching supervision can be carried out systematically through stages so that improvements made to the learning process can be focused and rational (Muttaqin, 2020). In addition to individual and group supervision, the implementation of teaching supervision can be carried out with clinical supervision (Hariadi, 2020). This clinical supervision aims to improve learning through planned and regular stages, observation and thorough analysis of the learning delivered by the teacher with the aim of improving the learning process. The principal has responsibility for improving the performance of teachers and in this case is responsible for teacher development. This guidance is carried out so that teachers can carry out their duties and responsibilities professionally. In conducting coaching the principal should set an example because as a leader in the school, and also his behavior will be an example for his staff in this case the teachers in the school he leads.

The ability of the principal in leading the education unit in this case, which consists of educators and education staff, completes educational facilities and infrastructure in accordance with the needs of the school (Lorensius, Ping, et al., 2021), will directly affect the quality of the school and will improve performance. teachers in terms of the learning process, so that it will be directly proportional to improving the quality of schools and graduates (Warman, Suryaningsi, et al., 2021). Principals are seen as a key factor to improve school effectiveness and performance (Day et al., 2016). The role of the principal in this position is unique because it is located between the public and internal areas of the school (Tolo et al., 2020), so that the principal in carrying out his leadership function requires the support, trust, and active involvement of all components (Sebastian et al., 2019), as well as creativity in innovating and 
advancing schools and improving student learning outcomes (Pietsch et al., 2019; Zhang et al., 2018; Heck \& Hallinger, 2014).

This study seeks to explore the impact of principals' leadership and supervision styles on school capacity. and teacher performance at public secondary schools in Kutai Kartanegara, East Kalimantan Province. The conceptualization of school leadership and supervision used in this study is guided by findings from several studies on principals' leadership and supervision styles (eg, Zuldesiah et al., 2021; Octavia \& Savira, 2017). Consistent with this theoretical perspective, our research discusses two questions regarding the leadership style and supervision of principals in improving teacher performance, namely how are efforts to improve teacher performance in public high schools in Kutai Kartanegara Regency in terms of principals' leadership and supervisory styles?, and what are the steps for providing academic supervision that can improve teacher competence in terms of academic potential and the ability to develop learning implementation plans?

\section{Methods}

This study uses a qualitative approach with a descriptive method cross-sectional with the aim of describing what is happening in the field. According to Sugiyono (2016) descriptive research is research that is used to describe or describe data that has been collected so that it becomes useful information. Observation and interview techniques were used to obtain data related to the leadership style and supervision of principals in improving teacher performance at public high schools in Kutai Kartanegara Regency, East Kalimantan Province by involving principals, teachers, and education staff. The data collected were analyzed in the form of data reduction, data presentation, and drawing conclusions (Miles \& Huberman, 1994), as well as checking the validity of the data using observation and triangulation (Sugiyono, 2017).

\section{Results and Discussion}

Leadership is a way or someone who acts as a commander in an organization or educational unit (Fry et al., 2005). Apart from being a leader, the principal also acts as a supervisor who functions as a coach and mentor for teachers in making improvements to the learning process (Almusaed, 2020). Carrying out their duties effectively, teaching supervisors are expected to be able to choose supervision techniques that are suitable for the objectives to be achieved. Professional coaching techniques that supervisors (principals) can use to improve learning processes and outcomes such as visiting classes, holding private meetings, teacher meetings, upgrading, utilizing model teachers, publishing professional bulletins, and meeting in work groups (Ali, 2019; Amon \& Anggal, 2021). Some of these coaching techniques, which technique is the most appropriate, depends on the situation and conditions of each teacher. Every coach must always strive to be able to improve the professional abilities of teachers, so that teachers are truly able to carry out their duties as educators; develop students' personalities, as teachers; develop students' thinking skills, and as trainers; develop students' skills (Pianda, 2018; Buan, 2021).

\subsection{Principal Leadership}

Principal leadership plays an important role in developing schools, especially to lead the collective learning process in schools through collaborative and informed reflection activities that are relevant to the needs of the school (Kovačević \& Hallinger, 2019). Leadership is needed to manage school development work and sustain change to improve teacher performance (Aas \& Paulsen, 2019). The success of the principal in school management, managing school infrastructure, fostering teachers, or managing other school activities is largely determined by the principal's leadership (Manora, 2019). Educational leadership style is the way the leaders of educational institutions organize, direct, and guide teachers so that they work together to achieve educational goals. Educational leadership is a position that demands the ability to read and understand the character, nature and personality of the teachers they lead.

The results of this study found that the leadership style of the principals of public high schools in Kutai Kartanegara Regency in improving the performance of their teachers was by trying to be an example in the school environment which was carried out in several ways, such as arriving early and leaving late. The leadership style applied by the principal in improving teacher discipline, from the interviews revealed that the leadership style used by the principal is a leadership telling style that is carried out by meeting teachers professionally. This telling leadership style is 
carried out by the principal at the teacher council meeting, in connection with the telling style of the principal it is also done by sitting in the teacher council office every morning, the principal monitors every teacher who comes and immediately reminds them when the clock shows it is time to teach inside. class.

Principals try to increase teacher work motivation by setting high work standards based on quality improvement. This is done because school principals are aware and understand that in essence their teachers are ordinary people and do not escape mistakes and also give full attention to following up on complaints and expectations that are expected by teachers to create quality school institutions. The leadership style of school principals in increasing teacher responsibility is carried out by giving awards, and other welfare outside the welfare set by the government on a national scale. With the award through special incentives, it is hoped that other needs can be increased. Principals also adopt a democratic leadership style in increasing the responsibilities of their teachers. In increasing teacher responsibilities, principals also try to encourage and direct teachers to work well in extracurricular and nonextracurricular learning activities.

The obstacles faced by principals in improving teacher performance were overcome by regulating class administration and enacting regulations on time, both in terms of attendance and the accuracy of the teaching schedule. The principal always reminds the teachers to always take care of their health, both themselves and their families at home. Efforts made by school principals in increasing the motivation of teachers are carried out through giving advice, enthusiasm, and regularly maintaining health, especially enthusiasm in teaching students at school. The obstacles faced by school principals in increasing teacher responsibility are that there are still teachers who are not able to describe the lesson plans and syllabus correctly, so that teachers only carry out teaching tasks without proper planning. Efforts made by school principals in addressing these problems are conducting training for teachers who are not yet regular in outlining learning implementation plans and syllabus, even principals often ask for help from supervisors and the education office to socialize related administration that must be prepared by teachers. before teaching.

\subsection{Principal's academic supervision program}

The results of our observations in a number of public high schools in Kutai Kartanegara Regency obtained information and descriptions of the problems that teachers prepare teaching tools when they are going to be promoted or graded and when there will be an assessment of school accreditation. Teachers' awareness to attend and leave school on time is still lacking. The improvement of teacher competence is not only through education and training but also through the opportunity to have the opportunity to continue their education to a higher level of education, because most of the high school teachers in Kutai Kartanegara district are still at the undergraduate level (S1). In addition, it is also necessary to pay attention in terms of increasing discipline, providing motivation, providing guidance through supervision, providing incentives, and proper salary.

Educational supervision is an effort to coordinate and continuously guide teachers in schools, both individually and in groups. The low performance of teachers in carrying out tasks at school is indicated by the ability of teachers to develop syllabus and lesson plans that are not optimal so as to create an unattractive learning atmosphere; ability in classroom management is still lacking, making it difficult to create a pleasant learning atmosphere; the teacher has not been fully maximized in utilizing the media so that the results in conveying material to students are not optimal; and teachers are less varied in using the learning model, so that boredom occurs in students during the teaching and learning process. If the problem of teacher performance is not immediately addressed, it will have an impact on decreasing the productivity produced by the teacher.

In this study, we found that the principals as supervisors have arranged a teaching supervision program together with the vice principal, the head of the expertise program, the head of teaching and the teachers through joint deliberation. This teaching supervision program is oriented towards improving teacher performance by having a cycle and stages of planning, observation, and intellectual analysis. Supervision is focused on improving teaching by running a systematic cycle from the stages of planning, observing, and intensive intellectual analysis of the teacher's teaching performance in the classroom. The teaching supervision program prepared by the principal is also oriented towards teaching programs, preparing learning tools, such as lesson reference units, lesson plans, evaluation tools, and preparing learning media for teachers. The results of our interviews found that the principal's supervision program had not lived 
up to expectations, because it did not include detailed targets and schedules regarding the implementation of the supervision.

The implementation of teaching supervision by principals on average is carried out only once a semester and there is also more than once for some teachers, so that the implementation of supervision is not evenly distributed to all teachers. The teacher performance improvement program through a meeting of subject teachers was attended by the principal, but did not invite a team of experts or resource persons who were competent in this field. The implementation of teaching supervision is not carried out by the principal alone, but is assisted by the vice principal and senior teachers. The principal can authorize other senior teachers who are really capable and experienced in carrying out supervision. Coaching activities for teachers are carried out through seminars, scientific meetings, interschool visits, and sometimes there are still principals who carry out authoritarian coaching so that the relationship between principals and teachers is not intimate.

Some of the obstacles in the implementation of supervision by the principal of public high schools in Kutai Kartanegara Regency are the low competence of some supervisors assigned by the principal; there are activities outside the supervision schedule that are not planned; and it is difficult to change old habits that have become school traditions. Most supervisor competencies are still weak, this is one of the inhibiting factors in the implementation of teaching supervision by school principals. Supervisors should analyze the condition of each teacher who will be supervised in more depth, not just by looking at outward appearances. The supervision program has been prepared, but in its implementation, it cannot be carried out according to the schedule due to activities outside the school plan. This happens because these activities are programs carried out by external parties of the school, such as teacher training by the center for the development and empowerment of educators and education personnel, meetings or meetings by the education office from the district, and other parties who have teacher competency improvement programs, such as educational quality assurance institutions and so on. The results of our study of a number of senior high schools in Kutai Kartanegara Regency found that only 50\% of teachers developed lesson plans. In terms of quality, the learning implementation plans that can be categorized as good only reach $30 \%$. Meanwhile, in terms of discipline, only $65 \%$ of teachers are disciplined in carrying out their duties professionally.

\section{Conclusion}

This study examines the leadership style and supervision of principals in improving teacher performance at public high schools in Kutai Kartanegara Regency, East Kalimantan Province. The results of this study indicate that the leadership style of principals in improving teacher performance is carried out by an authoritarian and democratic leadership style, by looking at the punctuality of entering class to teach students according to the schedule set by the school. The principal's democratic leadership style is carried out by providing opportunities for teachers to take part in various training according to the needs of the school and the needs of teachers. Principals also seek to improve teacher performance through awarding outstanding teachers, paying attention to teachers both in terms of material and nonmaterial, involving teachers in preparing school programs, listening to ideas conveyed by teachers and providing a sense of security to teachers. they. The teaching supervision program is oriented towards the guidance of teachers' tasks, such as preparing teaching programs and preparing learning tools. This is done through deliberation between the principal, vice principal, head of teaching, head of expertise programs, and senior teachers. However, there were also obstacles in the implementation of supervision, namely the low competence of some supervisors; there are activities outside the supervision schedule that are not planned; and the difficulty of changing old habits, such as the sometimes-authoritarian relationship between principals and teachers.

However, this research is not without limitations. Although this study can describe the leadership style and supervision of principals in improving teacher performance, this study was conducted with a limited number of participants and data and only in a few public high schools in Kutai Kartanegara Regency. Therefore, it is necessary to conduct new research with a larger number of participants and to include elementary and junior high schools in Kutai Kartanegara Regency. The results of this study can be used as a reference for further researchers for the success of their research. 


\section{Acknowledgements}

We would like to express our gratitude to all parties taking part in this study. Our gratitude also goes to the editor and the reviewers for their extremely helpful comments on previous versions of this paper, which we believe have improved it considerably.

\section{References}

Aas, M., \& Paulsen, J. M. (2019). National strategy for supporting school principal's instructional leadership: A Scandinavian approach. Journal of Educational Administration, 57(5), 540-553. https://doi.org/10.1108/JEA09-2018-0168

Ali, J. H. (2019). Peran Kepala Sekolah Sebagai Supervisor dalam Meningkatkan Mutu Pembelajaran Guru Mata Pelajaran IPA Pada SDN Roja 1 Ende. Jurnal Dinamika Sains, 3(1), 50-56.

Almusaed, A. (2020). The Role of the Supervisor on Developing PhD Students' Skills. International Conference on Humanities, Social and Education Sciences, July, 25-36. https://files.eric.ed.gov/fulltext/ED608952.pdf\#page=30

Amon, L., \& Anggal, N. (2021). Implementation of School-Based Management in Curriculum and Learning Processes: a Literatur Review. https://scholarzest.com/index.php/ejrds/article/view/1079

Andriani, S., Kesumawati, N., \& Kristiawan, M. (2018). The influence of the transformational leadership and work motivation on teachers performance. International Journal of Scientific and Technology Research, 7(7), 19-29.

Anggal, N., Kristianus, K., \& Lio, Z. D. (2019). Kepemimpinan Visioner Kepala Sekolah dalam Meningkatkan Kinerja Guru. Gaudium Vestrum: Jurnal Kateketik Pastoral, 3(1), 14-25. https://ojs.stkpkbi.ac.id/index.php/jgv/article/view/87

Bryk, A. S. (2010). Organizing Schools for Improvement. Phi Delta Kappan, 91(7), 23-30. https://doi.org/10.1177/003172171009100705

Buan, Y. A. L. (2021). Guru dan Pendidikan Karakter: Sinergitas Peran Guru Dalam Menanamkan Nilai-Nilai Pendidikan Karakter di Era Milenial. Penerbit Adab.

Dagnew Kelkay, A. (2020). School principals' and supervisors' leadership practices in teachers' continuous professional development program: in secondary school of Bahir Dar city, Ethiopia. International Journal of Leadership in Education, 23(4), 415-427. https://doi.org/10.1080/13603124.2018.1524933

Day, C., Gu, Q., \& Sammons, P. (2016). The Impact of Leadership on Student Outcomes. Educational Administration Quarterly, 52(2), 221-258. https://doi.org/10.1177/0013161X15616863

Donkoh, K. E., \& Baffoe, S. (2018). Instructional Supervisory Practices of Headteachers and Teacher Motivation in Public Basic Schools in Anomabo Education Circuit. Journal of Education and e-Learning Research, 5(1), 4350. https://doi.org/10.20448/journal.509.2018.51.43.50

Drummer, J., Hakimov, G., Joldoshov, M., Köhler, T., \& Udartseva, S. (2018). Vocational Teacher Education in Central Asia Developing Skills and Facilitating Success.

Fry, L. W., Vitucci, S., \& Cedillo, M. (2005). Spiritual leadership and army transformation: Theory, measurement, and establishing a baseline. Leadership Quarterly, 16(5), 835-862. https://doi.org/10.1016/j.leaqua.2005.07.012

Hallinger, P. (2004). Meeting the challenges of cultural leadership: The changing role of principals in Thailand. Discourse, 25(1), 61-73. https://doi.org/10.1080/0159630042000178482

Hariadi, F. (2020). Upaya Meningkatkan Kemampuan Guru dalam Mengembangkan Instrumen Penilaian Kelas melalui Supervisi Klinis Mata Pelajaran Bahasa Inggris di SMAN 4 Tanah Putih. Jurnal Pendidikan Tambusai, 4(3), 3457-3465. https://doi.org/https://www.jptam.org/index.php/jptam/article/view/886 
Heck, R. H., \& Hallinger, P. (2009). Assessing the contribution of distributed leadership to school improvement and growth in math achievement. American Educational Research Journal, 46(3), 659-689. https://doi.org/10.3102/0002831209340042

Heck, R. H., \& Hallinger, P. (2014). Modeling the longitudinal effects of school leadership on teaching and learning. Journal of Educational Administration, 52(5), 653-681. https://doi.org/10.1108/JEA-08-2013-0097

Irmayani, H., Wardiah, D., \& Kristiawan., M. (2018). The strategy of SD Pusri in improving educational quality. International Journal of Scientific and Technology Research, 7(7), 113-121. www.ijstr.org\%0D

Kaso, N., Mariani, M., Ilham, D., Firman, F., Aswar, N., \& Iksan, M. (2021). The Principal's Leadership: How to Improve the Quality of Teaching and Learning Process in State Junior High School of Luwu. Jurnal Ad'ministrare, 8(1), 49. https://doi.org/10.26858/ja.v8i1.19126

Kovačević, J., \& Hallinger, P. (2019). Leading school change and improvement: A bibliometric analysis of the knowledge base (1960-2017). Journal of Educational Administration, 57(6), 635-657. https://doi.org/10.1108/JEA-02-2019-0018

Lie, A., Andriono, T., \& Prasasti, S. (2014). Menjadi Sekolah Terbaik. RAS.

Lorensius, Ping, T., \& Poernomo, S. A. (2021). Tugas dan Fungsi Manajemen Pendidik dan Tenaga Kependidikan. Gaudium Vestrum: Jurnal Kateketik Pastoral, 5(1), 1-12. https://ojs.stkpkbi.ac.id/index.php/jgv/article/view/97

Lorensius, Warman, W., Silpanus, S., \& Ping, T. (2021). Leadership model and planning strategies in private Catholic colleges during the COVID-19 pandemic. International Journal of Educational Studies in Social Sciences (IJESSS), 1(2), 49-60. https://ijesss.com/journal/article/view/16/7

Manora, H. (2019). Peranan Kepala Sekolah Dalam Meningkatkan Mutu Pendidikan. Edification Journal, 1(1), 119125. https://doi.org/10.37092/ej.v1i1.88

Miles, M. B., \& Huberman, A. M. (1994). Qualitative data analysis: An Expanded Sourcebook. SAGE Publications.

Mustaghfiroh, M., Ariyanti, N. S., Adha, M. A., \& Sultoni, S. (2020). Upaya Peningkatan Komitmen Kerja Guru Bidang Studi (Studi Kasus di SMK Riyadlul Quran Kabupaten Malang). Jurnal Dinamika Manajemen Pendidikan, 5(1), 22. https://doi.org/10.26740/jdmp.v5n1.p22-28

Muttaqin, I. (2020). Supervision Planning at Islamic Education Institutions: Google Scholar Library Studies and Mendeley's Reference Manager. Istawa: Jurnal Pendidikan Islam, 5(2), 222. https://doi.org/10.24269/ijpi.v5i2.2847

Octavia, L. S., \& Savira, S. I. (2017). Gaya Kepemimpinan Kepala Sekolah dalam Upaya Meningkatkan Kinerja Guru dan Tenaga Kependidikan. Jurnal Dinamika Manajemen Pendidikan, l(1), 7. https://doi.org/10.26740/jdmp.v1n1.p7-14

Pianda, D. (2018). Kinerja guru: kompetensi guru, motivasi kerja dan kepemimpinan kepala sekolah. CV Jejak (Jejak Publisher).

Pietsch, M., Tulowitzki, P., \& Hartig, J. (2019). Examining the effect of principal turnover on teaching quality: a study on organizational change with repeated classroom observations. School Effectiveness and School Improvement, 1-23. https://doi.org/10.1080/09243453.2019.1672759

Rizkita, K., \& Supriyanto, A. (2020). Komparasi kepemimpinan pendidikan di Indonesia dan Malaysia dalam upaya peningkatan mutu pendidikan. Jurnal Akuntabilitas Manajemen Pendidikan, 8(2), 155-164. https://doi.org/10.21831/jamp.v8i2.32362

Rohaenah, I. N., Syah, S. M., \& Erihadiana, M. (2020). Implementasi Supervisi Kepala Sekolah Pada Kompetensi Pedagogik Guru. MISYKAT: Jurnal Ilmu-ilmu Al-Quran, Hadist, Syari'ah dan Tarbiyah, 5(2), 127. https://doi.org/10.33511/misykat.v5n2.127-140 
Rowland, C. (2017). Principal professional development new opportunities for a renewed state focus. American Institutes for Research, February, 28. www.edupolicycenter.org

Sebastian, J., Allensworth, E., Wiedermann, W., Hochbein, C., \& Cunningham, M. (2019). Principal Leadership and School Performance: An Examination of Instructional Leadership and Organizational Management. Leadership and Policy in Schools, 18(4), 591-613. https://doi.org/10.1080/15700763.2018.1513151

Sodik, M., Sahal, Y. F. D., \& Herlina, N. H. (2019). Pengaruh Kinerja Guru dalam Pelaksanaan Pembelajaran terhadap Prestasi Belajar Siswa pada Mata Pelajaran Alquran Hadis. Jurnal Penelitian Pendidikan Islam, 7(1), 97. https://doi.org/10.36667/jppi.v7i1.359

Sugiyono. (2016). Metode Penelitian Manajemen (Pendekatan Kuantitatif, Kualitatif, Kombinasi (Mixed Methods), Penelitian Tindakan (Action Research, dan Penelitian Evaluasi). Bandung: Alfabeta Cv.

Sugiyono. (2017). Metode Penelitian Bisnis: Pendekatan Kuantitatif, Kualitatif, Kombinasi, dan R\&D. Penerbit CV. Alfabeta: Bandung.

Thessin, R. A. (2019). Establishing productive principal/principal supervisor partnerships for instructional leadership. Journal of Educational Administration, 57(5), 463-483. https://doi.org/10.1108/JEA-09-2018-0184

Tolo, A., Lillejord, S., Flórez Petour, M. T., \& Hopfenbeck, T. N. (2020). Intelligent accountability in schools: A study of how school leaders work with the implementation of assessment for learning. Journal of Educational Change, 21(1), 59-82. https://doi.org/10.1007/s10833-019-09359-x

Walker, A., Hu, R., \& Qian, H. (2012). Principal leadership in China: An initial review. School Effectiveness and School Improvement, 23(4), 369-399. https://doi.org/10.1080/09243453.2012.678863

Warman. (2021). Establishing the governmental policy to promote engagement within the inclusive education system in Indonesia. Journal of Social Studies Education Research, 12(1), 124-148. https://www.learntechlib.org/p/219414/.

Warman, W., Lorensius, L., \& Rohana, R. (2021). Curriculum of Management in Improving the Quality of Catholic School Education in Samarinda City, East Kalimantan, Indonesia. Budapest International Research and Critics Institute (BIRCI-Journal): Humanities and Social Sciences, 4(3), 3677-3688. http://www.bircujournal.com/index.php/birci/article/view/2136

Warman, W., Suryaningsi, S., \& Widyatmike Gede, M. (2021). Overcoming obstacles in implementing 2013 curriculum policy. Cypriot Journal of Education, 16(3), 967-980. https://doi.org/https://doi.org/10.18844/cjes.v16i3.5770

Yulieana, R. (2020). Model School Curriculum Management at Public Elementary School. Journal of K6 Education and Management, 3(3), 315-326. https://doi.org/10.11594/jk6em.03.03.04

Zhang, Q., Siribanpitak, P., \& Charoenkul, N. (2018). Creative leadership strategies for primary school principals to promote teachers' creativity in Guangxi, China. Kasetsart Journal of Social Sciences, 41(2), 275-281. https://doi.org/10.1016/j.kjss.2018.08.007

Zuldesiah, Z., Gistituati, N., \& Sabandi, A. (2021). Kontribusi Gaya Kepemimpinan dan Pelaksanaan Supervisi Kepala Sekolah terhadap Kinerja Guru-guru Sekolah Dasar. Jurnal Basicedu, 5(2), 663-671. https://doi.org/10.31004/basicedu.v5i2.791 